\title{
MITOSIS OF RADIAL GLIAL CELLS IN THE OPTIC TECTUM OF ADULT GOLDFISH ${ }^{1}$
}

\author{
JAMES A. STEVENSON ${ }^{2}$ AND MYONG G. YOON \\ Department of Psychology, Life Sciences Centre, Dalhousie University, Halifax, Nova Scotia, Canada B3H $4 J 1$
}

\begin{abstract}
A class of tectal cells whose mitotic activity is enhanced by optic nerve regeneration in adult goldfish has been identified as radial neuroglia. These mitotic glial cells are morphologically distinct cells with prominent radial processes which extend through the entire depth of the tectal layers. The radial glia incorporate exogenous $\left[{ }^{3} \mathrm{H}\right]$ thymidine $\left(\left[{ }^{3} \mathrm{H}\right] \mathrm{TdR}\right)$ into DNA as early as $2 \mathrm{hr}$ after systemic injection. The plane of cell division for the mitotic radial glia is always aligned to the equator of the cell body, perpendicular to the direction of the radial process. In a few cases, radially adjacent pairs of labeled daughter radial glial cells are observed as early as $12 \mathrm{hr}$ and also as late as 51 days after $\left[{ }^{3} \mathrm{H}\right] \mathrm{TdR}$ injection. In other cases, however, only one labeled daughter radial glial cell is identified, and the other daughter cell cannot be traced. These observations suggest that radial glial cells of the adult goldfish tectum can be induced (presumably by mitogenic effects of regenerating optic nerve fibers) to undergo mitosis.
\end{abstract}

Recent studies on cell proliferation in the adult goldfish tectum have shown that regeneration of severed optic nerve fibers enhances the rate of cell birth, as determined by $\left[{ }^{3} \mathrm{H}\right]$ thymidine $\left(\left[{ }^{3} \mathrm{H}\right] \mathrm{TdR}\right)$ labeling, in the contralateral tectum (Stevenson, 1976, 1977; Johns et al., 1977; Stevenson and Yoon, 1978, 1980). When optic nerves were crushed and allowed to regenerate, we observed the following kinetic features of $\left[{ }^{3} \mathrm{H}\right] \mathrm{TdR}$ incorporation in the goldfish tectum (Stevenson and Yoon, 1978). In the superficial tectal layers, which include the main passage of optic fibers (the stratum opticum) and the zone of their termination (the stratum fibrosum et griseum superficiale), the number of labeled cells examined 2 days after $\left[{ }^{3} \mathrm{H}\right] \mathrm{TdR}$ exposure increases with two peaks at 5 and 25 days after optic nerve crush. This bimodal increase over normal levels subsides by 40 days after unilateral optic nerve crush. The cell labeling in the superficial tectal layers rapidly diminishes with extended survival times after $\left[{ }^{3} \mathrm{H}\right]$ thymidine injection. There is, however, a unique class of newly born cells in the deep tectal layers which retain a nuclear $\left[{ }^{3} \mathrm{H}\right] \mathrm{TdR}$ label for extended periods. These labeled cells have cell bodies located in the periependymal zone, a narrow layer (one or two cells thick) which is interposed between the ependymal region

\footnotetext{
${ }^{1}$ This work was supported by grants from the Natural Science and Engineering Research Council (A9756) and the Medical Research Council (MA4994) of Canada. We wish to thank Mai Riives and Frank Baker for technical assistance, and Mary McConnachie for typing.

${ }^{2}$ To whom correspondence should be addressed at his present address: Department of Anatomy, Medical University of South Carolina, 171 Ashley Avenue, Charleston, SC 29403.
}

and the stratum periventriculare (Stevenson and Yoon, 1978, 1980; J. A. Stevenson and M. G. Yoon, submitted for publication). These newly born "periependymal" cells retain labeled DNA in their nuclei and do not show any sign of migration from the periependymal zone throughout the experimental periods studied (up to 6 months after $\left[{ }^{3} \mathrm{H}\right] \mathrm{TdR}$ injection). The rate of their incorporation of $\left[{ }^{3} \mathrm{H}\right] \mathrm{TdR}$ was increased maximally about 4 to 5 weeks after the contralateral optic nerve crush (Stevenson and Yoon, 1978). This time of maximal $\left[{ }^{3} \mathrm{H}\right]^{\prime} \mathrm{T} d \mathrm{dR}$ labeling corresponds to the earliest time at which visually elicited neural responses (presumably from the postsynaptic tectal neurons) may be recorded in an optic tectum following crush of the contralateral optic nerve (Yoon, 1976). On the other hand, eye enucleation, which produces axonal degeneration (similar to that produced by optic nerve section) but eliminates any optic fiber regeneration, fails to enhance the rate of "periependymal" cell labeling (Stevenson and Yoon, 1978). These findings suggest that regenerating optic fibers may exert a mitogenic influence on the "periependymal" (PF) cells (Stevenson and Yoon, 1978, 1980). Are these PE cells the visual neurons which receive direct synaptic inputs from the retinal ganglion cells? Are they glial cells or other tectal neurons which do not form any direct synaptic linkage with the retinal ganglion cells? What are the precursor cells which give rise to the newly born PE cells?

There are three distinct cell populations-periventricular neurons, ependymal cells, and radial glia-which reside in the deep layers of the optic tectum in adult goldfish. Stevenson and Yoon (J. A. Stevenson and M. G. Yoon, submitted for publication) observed the follow- 
ing morphological features which distinguish these three cell populations in the normal goldfish tectum. A radial glial cell shows a characteristic invagination of its nucleus with prominent clefts. Its cytoplasm contains $20-\mathrm{nm}$ microtubules and mitochondria with $35-\mathrm{nm}$ dark granules but no microfilaments. Its prominent radial process extends through the superficial tectal layers. In contrast, the processes of an ependymal cell ramify and interweave within the ependymal region. The cytoplasm of an ependymal cell contains prominent bundles of $7-\mathrm{nm}$ microfilaments but no microtubules. A periventricular neuron has a regular round nucleus and a smooth dendrite which extends toward the superficial tectal layers. Its cytoplasm contains microtubules and mitochondria without any dark granules. Axosomatic and axodendritic synapses are found on periventricular neurons.

In the present work, morphological features of the ["H J'l'dR-labeled "periependymal" cells are used to identify them as radial glia, and the mitotic activities and lineage of this cell type are studied in the optic tectum of adult goldfish. A preliminary account of the results has been reported elsewhere (Stevenson, 1979).

\section{Materials and Methods}

Common goldfish (Carassius auratus) used in the present experiments ranged in length from 65 to $90 \mathrm{~mm}$ and weighed between 10 and $20 \mathrm{gm}$. They were sexually mature, adult fish obtained from Mt. Parnell Fisheries (Mercersburg, PA). Fish were anesthetized individually by submersion in a 0.05 to $0.1 \%$ solution of ethyl $m$ aminobenzoate methanesulfonate (MS 222, Sandoz), and the optic fibers were sectioned by crushing the optic nerve within its meningeal sheath at a position about 1 $\mathrm{mm}$ from the posterior pole of the eyeball. Crushing was repeated several times until the distal and the proximal nerve stumps were clearly separated. The operated fish were maintained at 20 to $22^{\circ} \mathrm{C}$ on a 12 -hr light:12-hr dark daily cycle throughout the experimental period.

In order to label those cells which incorporated exogenous thymidine into new DNA, the experimental fish were injected intraperitoneally with 20 to $50 \mu \mathrm{Ci}$ of tritiated thymidine $\left(\left[{ }^{3} \mathrm{H}\right] \mathrm{TdR}, 6.7\right.$ or $20 \mathrm{Ci} / \mathrm{mmol}$, New England Nuclear) at predesignated postoperative periods between 29 and 38 days after optic nerve crush. These $\left[{ }^{3} \mathrm{H}\right] \mathrm{TdR}$-injected fish were sacrificed after postinjection survival times varying between $2 \mathrm{hr}$ and 51 days.

At the time of sacrifice, the experimental fish were anesthetized deeply and perfused with $0.5 \mathrm{ml}$ of sodium cacodylate buffer (pH 7.2 to 7.4 ) followed by 10 to $20 \mathrm{ml}$ of a mixed aldehyde fixative. After osmication and dehydration, the fixed tectal tissues were embedded in Epon 812 , and a series of $1-\mu \mathrm{m}$ semithin sections were cut and prepared for light microscopic autoradiography. For electron microscopic examination of the same tissue, thin sections were taken immediately adjacent to the semithin sections.

Autoradiograms of semithin sections were prepared by dipping slides in liquid emulsion (NTB-2, Kodak) diluted 1:1 with distilled water (Sidman, 1970). They were exposed for 4 to 6 weeks at $4^{\circ} \mathrm{C}$ in the dark and then developed for $2 \mathrm{~min}$ in D-19 (Kodak) and fixed. They were counterstained with $75 \%$ Richardson's stain at $40^{\circ} \mathrm{C}$ and differentiated in $70 \%$ ethanol. In later experiments, the scintillation technique for autoradiography (Panayi and Neill, 1972; Smith et al., 1979) was employed to shorten the long exposure time for semithin section autoradiograms. Sections were coated with emulsion as described above, but, during the exposure period, they were stored in a refrigerated light-tight container filled with liquid scintillation cocktail (LSC, Aquasol, New England Nuclear). After 5 to 10 days exposure, these slides were removed from the LSC, washed in several changes of xylene to remove the remaining film of LSC, and then developed and fixed.

For the electron microscopy, the same procedures were used as described elsewhere (J. A. Stevenson and M. G. Yoon, submitted for publication).

\section{Results}

\section{Identification of "periependymal" cells}

Autoradiography. To promote the proliferation of "periependymal" (PE) cells and to facilitate their identification, optic nerves were crushed and allowed to regenerate back to the contralateral tectum. About 4 to 5 weeks after optic nerve crush, $\left[{ }^{3} \mathrm{H}\right]$ thymidine was injected into the experimental fish to label those cells synthesizing DNA at this period. After various postinjection intervals between $2 \mathrm{hr}$ and 51 days, the injected fish were sacrificed and their brains were processed for autoradiography.

Semithin section autoradiograms of the experimental tectal tissues frequently displayed the $\left[{ }^{3} \mathrm{H}\right] \mathrm{TdR}$-labeled nuclei lying inmediately deep to the stralum periventriculare (SPV). Figure 1 shows examples of the labeled cells, whose nuclei are located in the intermediate zone (i.e., the periependymal layer), interposed between the ependyma and the SPV. Two labeled PE cells are indicated by large arrows near their nuclei. The cytoplasmic boundary of the labeled PE cell (shown on the right side of Fig. 1) is outlined by small arrows as it extends superficially into the SPV. Note two other unlabeled cells (indicated by arrowheads in Fig. 1). Their nuclei are located in the same periependymal layer, and their nuclear forms are indistinguishable from those of the labeled PE cells. Figures 2 and 3 reveal a characteristic feature that both the labeled PE cells (marked by arrows) and the unlabeled cells (marked by arrowheads) in the periependymal layer have in common. Their nuclei display prominent invaginations in contradistinction to the uniformly round nucleus of a SPV neuron (marked by $N$ ). This nuclear invagination is a characteristic feature of the radial glia in the goldfish optic tectum as described in detail elsewhere (J. A. Stevenson and M. G. Yoon, submitted for publication). Each of the 200 labeled PE cells examined has shown these prominent invaginations in its nucleus.

The nucleoplasm stained with different intensity in different PE cells and was only slightly heterochromatic. The nucleoli of labeled PE cells were generally situated adjacent to the nuclear membrane as were those of unlabeled radial glia (Figs. 2 and 3 ).

The characteristic invaginations of their nuclei and possession of a prominent, outward directed process (Fig. 1) which extends into the SPV, as well as the location 

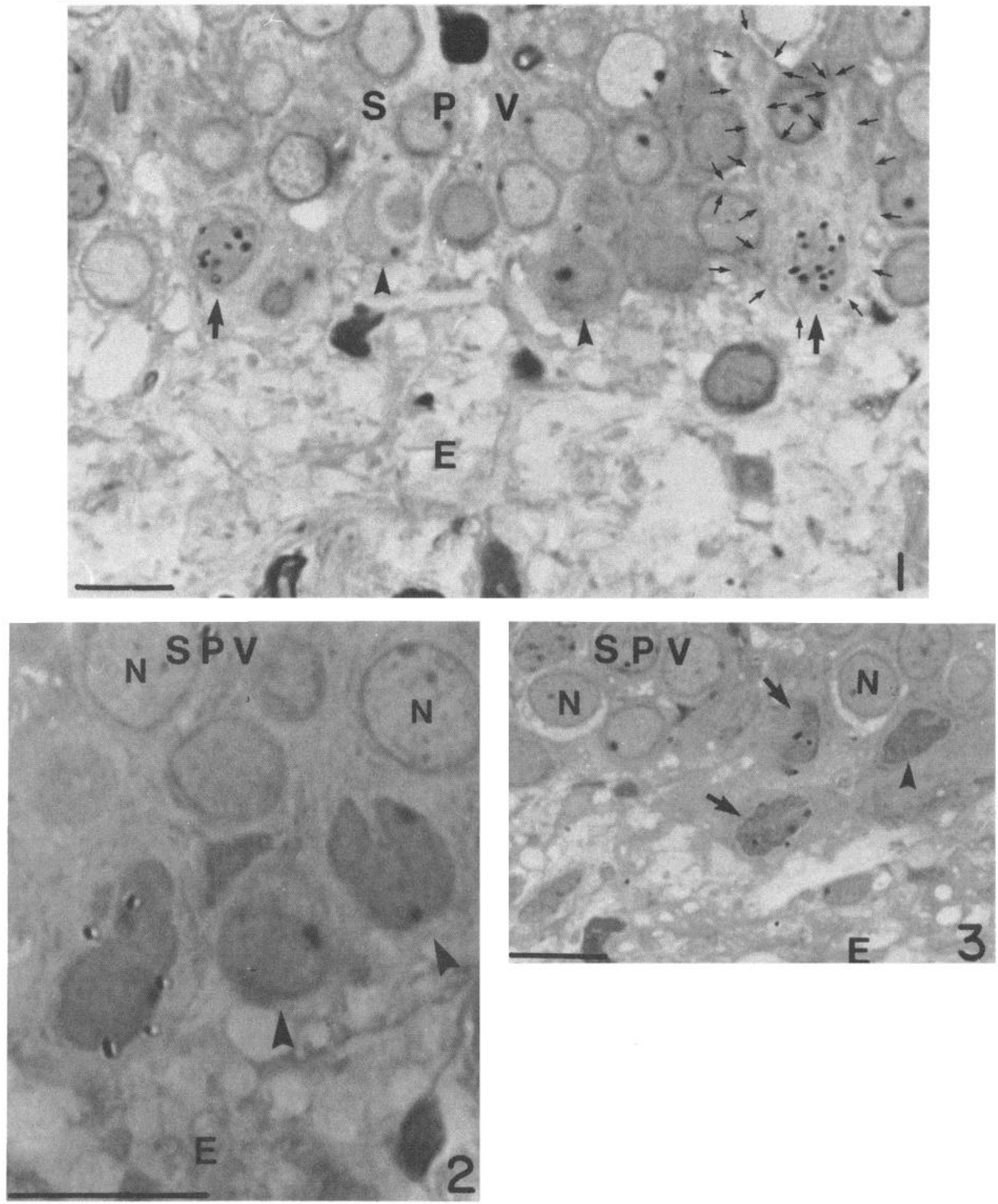

Figure 1 (upper). Autoradiogram of the deep tectal layers of a goldfish injected with $\left[{ }^{3} \mathrm{H}\right]$ thymidine $\left(\left[{ }^{3} \mathrm{H}\right] \mathrm{TdR}\right) 32$ days after contralateral optic nerve crush and sacrificed 51 days after injection. Two labeled "periependymal" cells are indicated by the large arrows. The cytoplasmic boundary of the PE cell on the right is outlined by small arrows as it extends into the stratum periventriculare $(S P V)$. Two unlabeled radial glial cells are indicated at the arrowheads. $E$, ependymal region. Scale bar $=10$ $\mu \mathrm{m}$.

Figure 2 (lower left). Details of one $\left[{ }^{3} \mathrm{H}\right] \mathrm{TdR}$-labeled PE cell nucleus and two radial glial nuclei (arrowheads). This section was taken from a fish which received three consecutive injections of $\left[{ }^{3} \mathrm{H}\right] \mathrm{TdR}$ at 24,28 , and 32 days after optic nerve crush and was sacrificed 31 days after the final injection. The labeled nucleus of this PE cell shows a prominent invagination. The nucleoli are adjacent to the nuclear membrane. $N$, nucleus of a periventricular neuron. Scale bar $=10 \mu \mathrm{m}$.

Figure 3 (lower right). Autoradiogram showing a radially adjacent pair of labeled PE cells (arrows). A radial glial cell is indicated at the arrowhead. This tissue was obtained from a fish which was injected with $\left[{ }^{3} \mathrm{H}\right] \mathrm{TdR}$ three times at 24,28 , and 32 days after optic nerve crush and sacrificed 31 days after the final injection. An electron micrograph of an adjacent thin section is shown in Figure 5. Scale bar $=10 \mu \mathrm{m}$. 

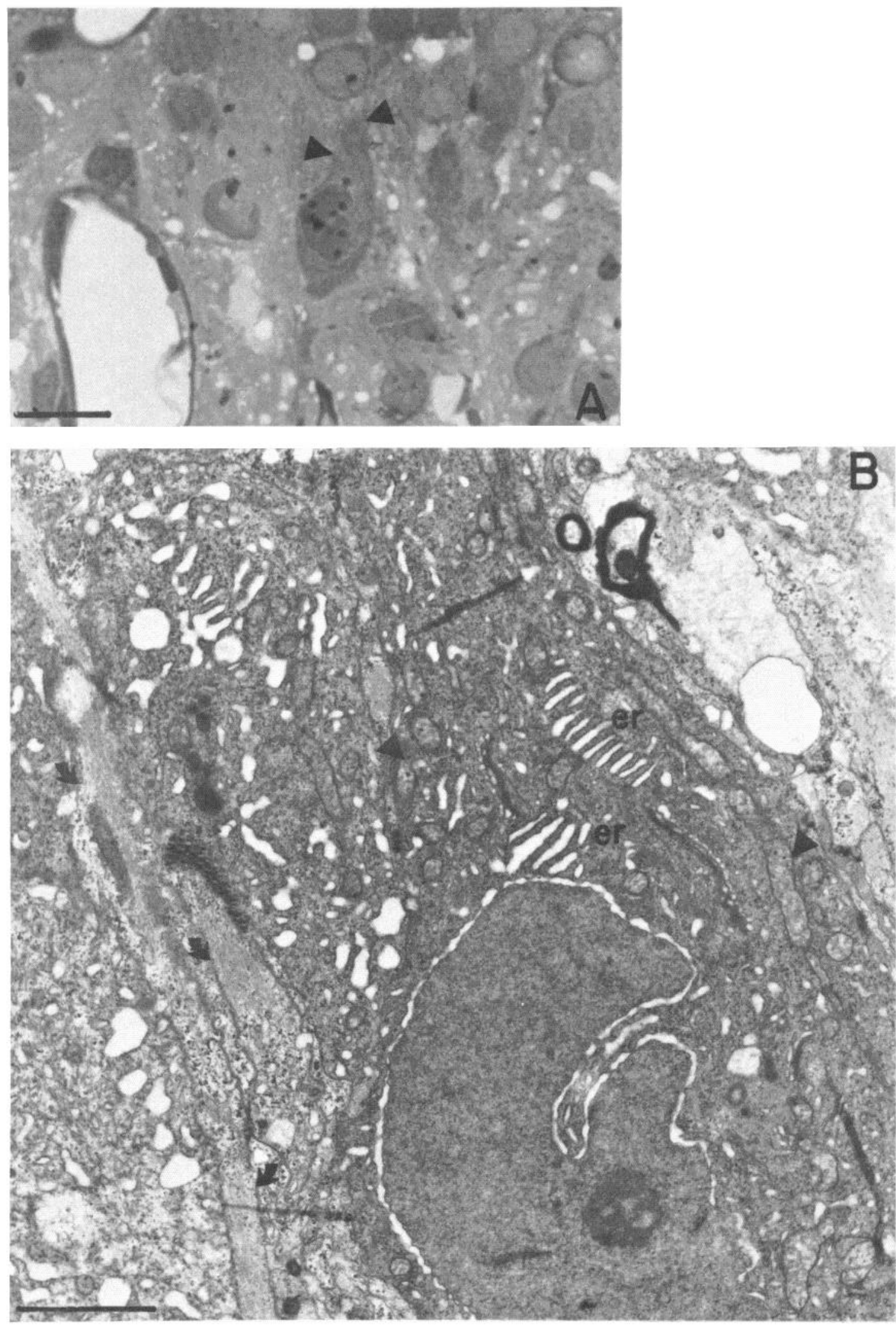

Figure 4. A, Light microscopic autoradiogram of a $\mathrm{PE}$ cell which was labeled $2 \mathrm{hr}$ after $\left[{ }^{3} \mathrm{H}\right] \mathrm{TdR}$ injection. Note that a prominent process (between arrowheads) extends from its soma and passes by a SPV neuron. Scale bar $=10 \mu \mathrm{m}$. B, Electron micrograph of an adjacent thin section of the same PE cell. Its nucleus shows a prominent invagination. The mitochondria in its cytoplasm conıain dark granules (arrowheads). Adjacent ependymal cell processes, filled with microfilaments, are indicated by arrows. er, endoplasmic reticulum. Scale bar $=2 \mu \mathrm{m}$. 
and morphology of the somata of these labeled PE cells, strongly suggest that they are identical to the radial glia as described by Stevenson and Yoon (J. A. Stevenson and M. G. Yoon, submitted for publication).

Electron microscopy. $\left[{ }^{3} \mathrm{H}\right]$ Thymidine-labeled PE cell nuclei were identified initially in semithin sections by light microscopic autoradiography, and then the adjacent sections were examined under an electron microscope. Figure 4 shows an example of such consecutive examinations. The autoradiogram (Fig. $4 A$ ) reveals the labeled

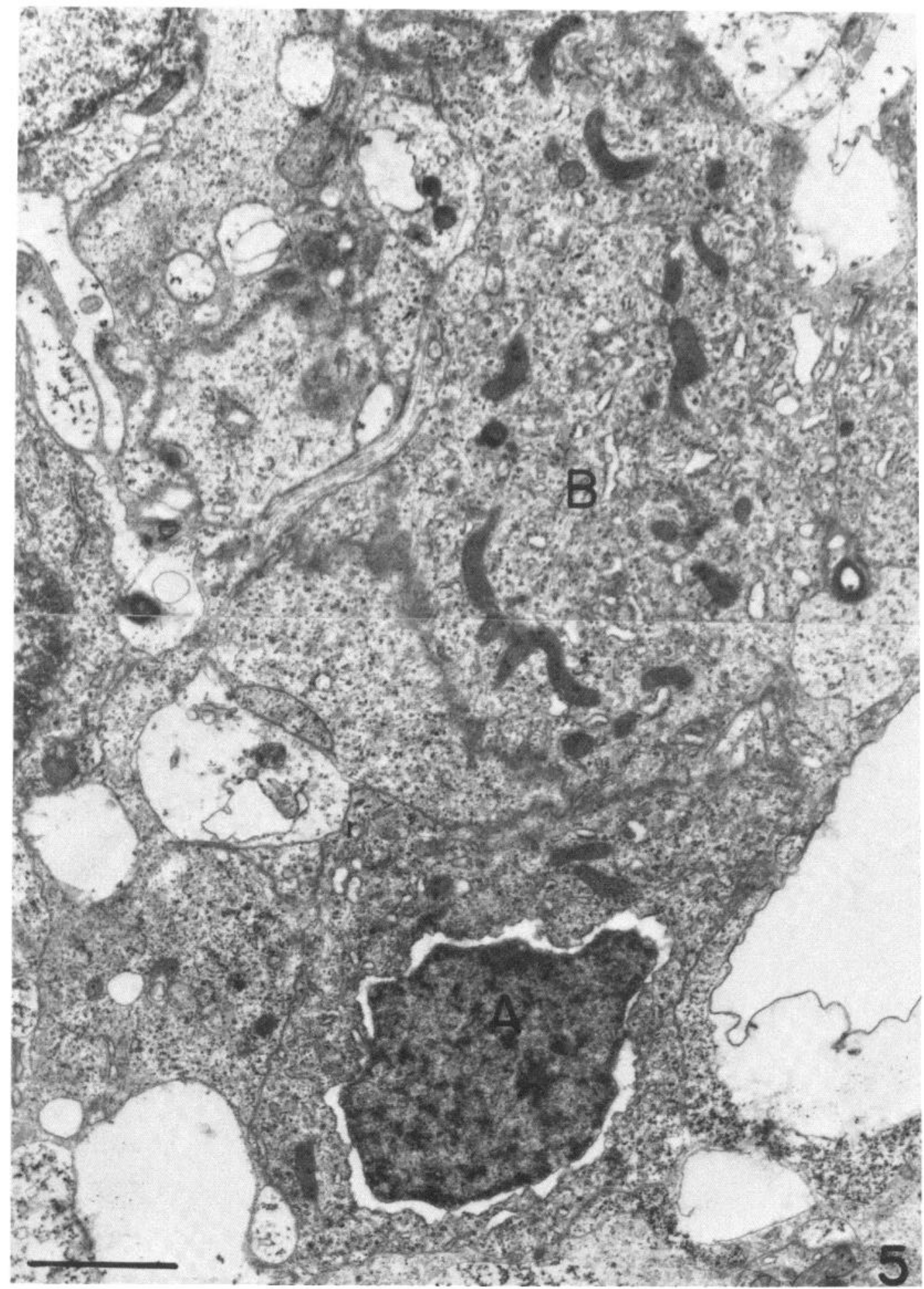

Figure 5. Electron micrograph of the pair of PE cells whose labeled nuclei are shown in Figure 3 . The nucleus of the lower cell $(A)$ is heterochromatic and surrounded by a widely dilated nuclear envelope. The nucleus of the upper cell $(B)$ is not seen in this section. The cytoplasm of the latter cell contains microtubules and mitochondria with dark granules. Scale bar $=2 \mu \mathrm{m}$. 
nucleus of a PE cell. The initial region of the prominent radial process of this PE cell stands out as it approaches a SPV neuron. The labeled nucleus of the PE cell shows the characteristic invaginations. Also note that the adjacent unlabeled radial glial cell (at left) shows the characteristic nuclear invaginations. The electron micrograph (Fig. $4 B$ ) of an adjacent section shows a portion of the perikaryon and the radial process of the same labeled $\mathrm{PE}$ cell. As in the semithin sections, the nuclear morphology of the labeled PE cell is its most distinctive feature. The clefts of the nucleoplasm are accentuated in the electron micrograph by the extensive dilation of the surrounding nuclear envelope. The nucleoplasm of this cell contains light chromatic aggregates and a prominent nucleolus. Its cytoplasm is moderately electron dense, in contrast to that of the surrounding processes of ependymal cell (at arrows). Figure 5 shows details of the cytoplasmic organelles of a radially oriented pair of labeled PE cells which have been identified previously in the light microscopic autoradiogram in Figure 3. Unfortunately, the nucleus of one cell is not seen in this electron micrograph section. The perikarya of these labeled PE cells possess distinctive mitochondria which contain dark granules, about $35 \mathrm{~nm}$ in diameter. Such granule content is a feature characteristic of glial mitochondria in the goldfish tectum (J. A. Stevenson and M. G. Yoon, submitted for publication). These mitochondria often show a dense matrix with irregular transversely oriented cristae. Other important features of the labeled PE cell's cytoplasm are the presence of a prominent system of $20-\mathrm{nm}$ microtubules and the absence of microfilaments. Note that these were also characteristic features of the radial glial cell, distinguishing it from an ependymal cell (J. A. Stevenson and M. G. Yoon, submitted for publication).

The above cytological features of a $\left[{ }^{3} \mathrm{H}\right] \mathrm{TdR}$-labeled $P E$ cell indicate that it is identical to the radial glial cell in the periependymal layer of the goldfish optic tectum.

\section{Lineage of the periependymal radial glial cells}

To identify the precursor cells which give rise to the newly born radial glial cells, $\left[{ }^{3} \mathrm{H}\right]$ thymidine was administered to 34 experimental goldfish between 28 and 38 days after optic nerve crush, and their optic tecta were examined at various intervals between $2 \mathrm{hr}$ and 51 days after injection. From 12 expcrimental animals, labeled radial glial cells in different stages of their cell cycle were identified within the periependymal zone of the optic tectum. Table I summarizes the staging and timing of these $\left[{ }^{3} \mathrm{H}\right] \mathrm{T} d \mathrm{R}$-labeled cells.

Premitotic period. The nucleus of a radial glial cell was labeled as early as $2 \mathrm{hr}$ after $\left[{ }^{3} \mathrm{H}\right]$ thymidine injection in two cases, one of which has already been shown in Figure $4, A$ and $B$. This finding indicates that pre-existing, well differentiated radial glial cells incorporate exogenous thymidine presumably in preparation for cell division. They remain in a premitotic state for about 10 $\mathrm{hr}$; in six fish sacrificed between 2 and $10 \mathrm{hr}$ after $\left[{ }^{3} \mathrm{H}\right]$ $\mathrm{TdR}$ injection, all labeled radial glia were found to be in interphase. Labeling was confined to the well defined euchromatic nucleus of each cell. None of the labeled cells showed any sign of mitosis at this early stage (within $10 \mathrm{hr}$ after injection). During this premitotic period, the
TABLE I

Mitotic stages of $\left[{ }^{3} \mathrm{H}\right]$ thymidine-labeled radial glial cells

\begin{tabular}{ccl}
\hline $\begin{array}{c}{\left[{ }^{3} \mathrm{H}\right] \mathrm{TdR}} \\
\text { Injection Date } \\
\text { After Optic } \\
\text { Nerve Crush }\end{array}$ & $\begin{array}{c}\text { Postinjection } \\
\text { Sacrifice Time }\end{array}$ & \multicolumn{1}{c}{ Mitotic Stages } \\
\hline days & & \\
33 & $2 \mathrm{hr}$ & Interphase \\
37 & $2 \mathrm{hr}$ & Interphase \\
37 & $4 \mathrm{hr}$ & Interphase \\
37 & $6 \mathrm{hr}$ & Interphase \\
37 & $8 \mathrm{hr}$ & Interphase \\
37 & $10 \mathrm{hr}$ & Interphase \\
33 & $12 \mathrm{hr}$ & Interphase, telophase \\
33 & $24 \mathrm{hr}$ & Interphase, telophase, \\
& & radial pairs, \\
& & oblique pairs \\
28 & $24 \mathrm{hr}$ & Interphase, telophase \\
33 & $48 \mathrm{hr}$ & Pairs, interphase \\
33 & $5 \mathrm{days}$ & Pairs, singles \\
32 & $51 \mathrm{days}$ & Pairs, singles \\
\hline
\end{tabular}

interphase radial glial cells must have duplicated DNA and probably altered their metabolism in preparation for cell division. The prominent stacks of rough endoplasmic reticulum ( $e r$ in Fig. $4 B$ ) in the cytoplasm of a premitotic radial glial cell is an unusual feature which is rarely encountered in a postmitotic radial glial cell (J. A. Stevenson and M. G. Yoon, submitted for publication).

Mitotic period. Between 12 and $24 \mathrm{hr}$ after $\left[{ }^{3} \mathrm{H}\right] \mathrm{TdR}$ injection, labeled radial glial cells were in different stages of mitosis (Table I). Radial glial cells in prophase had normally shaped cell bodies but darker than normal cytoplasm. Their chromatin had condensed and no nuclear membrane was present. Instead, a lighter region of the cytoplasm, not enclosed by a nuclear membrane, contained the chromosomes (Figs. 6 and 7).

The radial glial cells at metaphase have several distinctive features. Figure 8 shows two cells entering metaphase. In both cells, the chromosomes are arranged in a place traversing the equator of the cell body. This equatorial metaphase arrangement was common to all mitotic radial glial cells (Fig. 9). The cytoplasm of the surrounding mitotic spindle was lighter than that of the remainder of the soma. Electron micrographs of radial glial cells near metaphase are shown in Figures 10 and 11. The prominent feature of these cells is their condensed chromosomes which are arranged along the equator of their cell bodies. Other cytoplasmic organelles, the granule-containing mitochondria in particular, are excluded from the central somatic region. Cisternae often run parallel to the equatorial chromosome masses. The initial portion of an intact radial process extends from the mitotic cell as shown in Figure 10A. Some of the mitochondria are pushed to the outward radial processes (Fig. 10B), while some are clustered at the other pole of the soma in the region of the process, directed toward the ventricle.

Figure 12 shows a radial glial cell at an early anaphase. The chromosomes, arranged along the equatorial plane, are pulled toward the superficial and the ventricular poles of the cell. The outward radial process of this mitotic cell extends well into the SPV.

During telophase, the nuclear envelopes re-form 

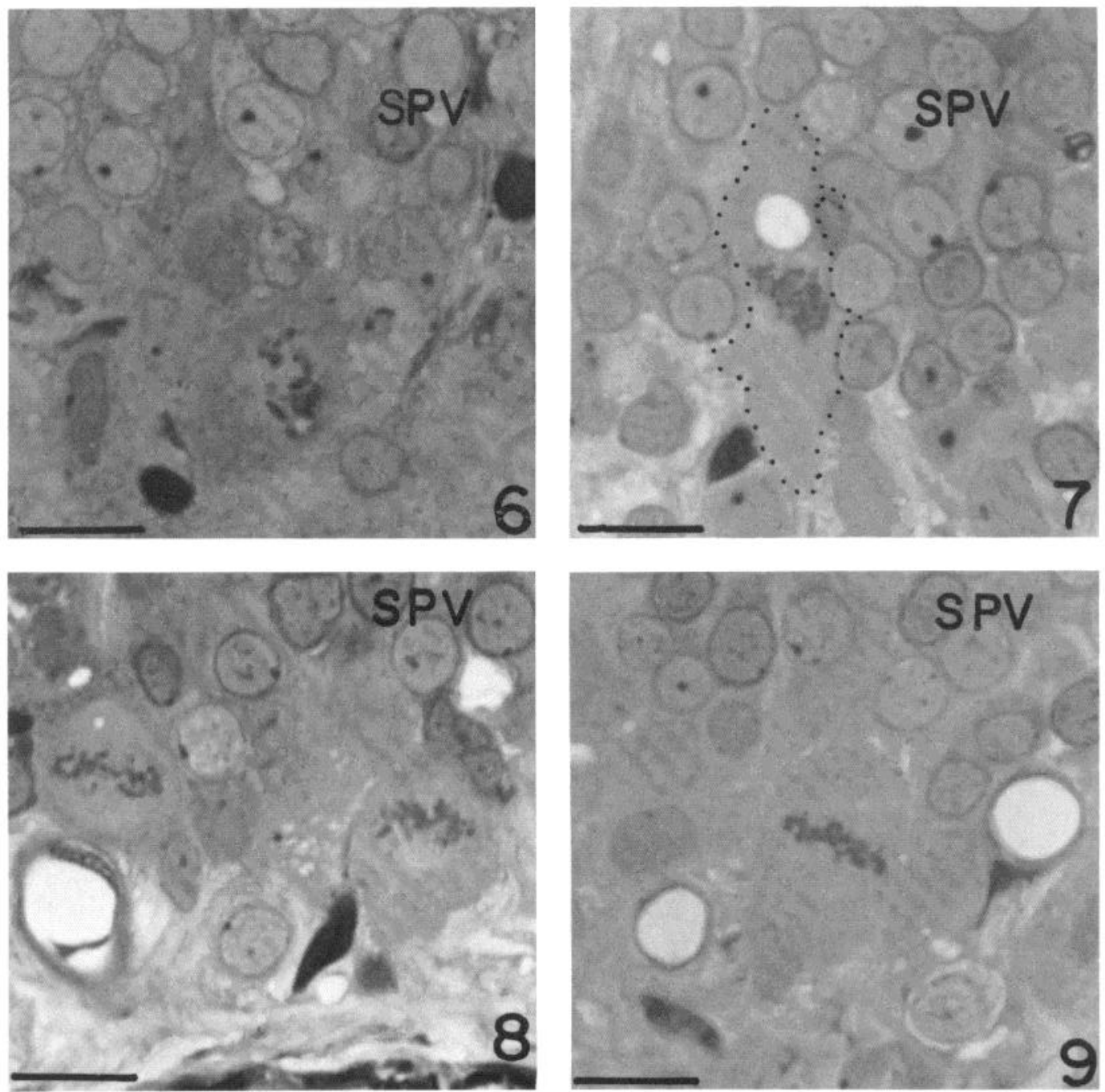

Figure 6 (upper left). A mitotic radial glial cell in early prophase. Clumps of chromatin are situated within the central region although no nuclear membrane is visible. Scale bar $=10 \mu \mathrm{m}$.

Figure 7 (upper right). A radial glial cell in late prophase. The condensed chromatin of this cell appears within the lower region of SPV and its cytoplasm (outlined by dotted lines) extends from the periependymal region into the upper SPV. Scale bar $=10 \mu \mathrm{m}$.

Figure 8 (lower left). Two radial glial cells at metaphase. Note that the chromosomes are aligned along the equators perpendicular to the direction of the radial process in both cells. Scale bar $=10$ $\mu \mathrm{m}$.

Figure 9 (lower right). Another radial glia showing equatorial alignment of the chromosomes at metaphase. Scale bar $=10 \mu \mathrm{m}$.

around the horizontally elongated masses of chromatin as shown in Figure 13. The two labeled daughter chromatin masses of this mitotic radial glial cell are marked 1 , for that located superficially, and 2 , for that located closer to the ventricle, in Figure 13, $A$ and $B$. The electron micrograph (Fig. 13C) shows that each daughter cell contains a dark heterochromatic nucleus. Their cytoplasm has plentiful mitochondria, but Golgi apparatus is not well formed yet. A large number of short endoplasmic reticulum cisternae are present in the dark cytoplasm.

Figures 14 and 15 show consecutive sections through a pair of labeled daughter cells (marked 1 and 2). These daughter cells are adjacent to one another in radial orientation as shown in the light microscopic autoradiograms (Figs. 14 $A$ and 15A). They are the products of a recent mitotic division only $12 \mathrm{hr}$ after $\left[{ }^{3} \mathrm{H}\right] \mathrm{TdR}$ injection. The electron micrographs of both daughter cells indicate that they are radial glial cells. Their nuclei are dark and moderately heterochromatic. The nucleoplasm of each cell contains small granular aggregates of chromatin. The nuclear envelopes are complete in both cells. Both perikarya contain free ribosomes and endoplasmic reticulum as well as the mitochondria with dark granules and microtubules characteristic of radial glial cells.

Postmitotic period. The equatorial alignment of metaphase chromosomes and their polar migration during anaphase and telophase are followed by the appearance of radially adjacent pairs of labeled cells. These pairs were observed as early as $24 \mathrm{hr}$ after $\left[{ }^{3} \mathrm{H}\right] \mathrm{TdR}$ injection (as shown in Fig. 16), others were seen $48 \mathrm{hr}$ 

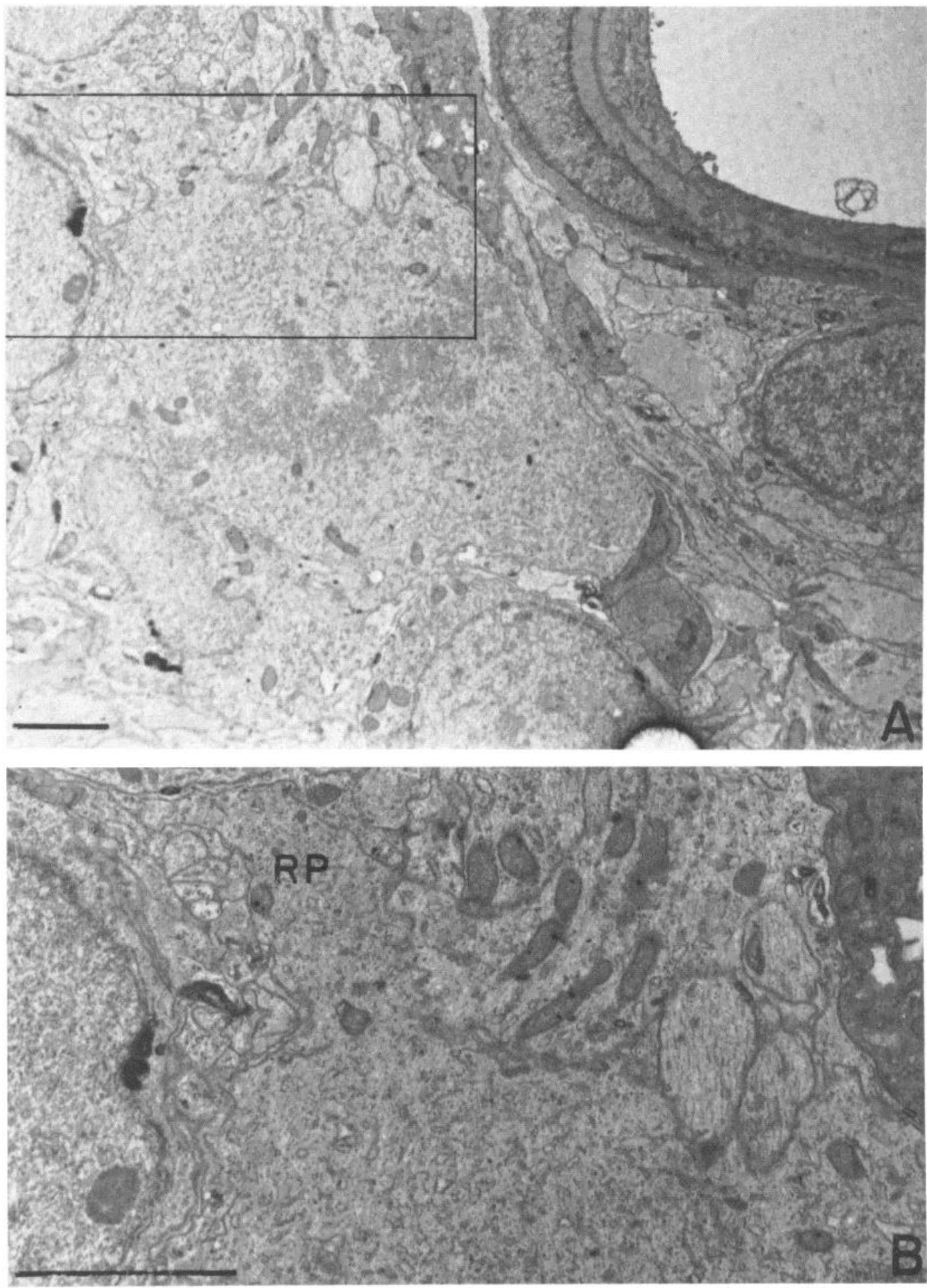

Figure 10. A, Electron micrograph of a mitotic radial glial cell at metaphase. The condensed chromosomes are aligned along the equator of the cell's soma. $B$, An enlargement of the boxed area of $A$ showing an initial portion of the radial process $(R P)$. Scale bars $=2 \mu \mathrm{m}$ for $A$ and $B$.

after injection (Figs. 17 and 18), and some appeared as late as 51 days after injection (Fig. 19). At later stages, however, single labeled cells were observed also. Figure 20 shows two separate radial glial cells labeled $48 \mathrm{hr}$ after $\left[{ }^{3} \mathrm{H}\right] \mathrm{TdR}$ injection. The electron micrographs reveal that their labeled nuclei are euchromatic and moderately electron dense. The nuclear envelopes are swollen as are other endoplasmic reticulum profiles. The cytoplasm of these labeled cells contains mitochondria with dark granules, free ribosomes, Golgi apparatus, and a few microtubules characteristic of radial glial cells.

\section{Discussion}

The present work shows that the "periependymal" cells, a class of tectal cells whose mitotic activity is enhanced by optic nerve regeneration (Stevenson and 

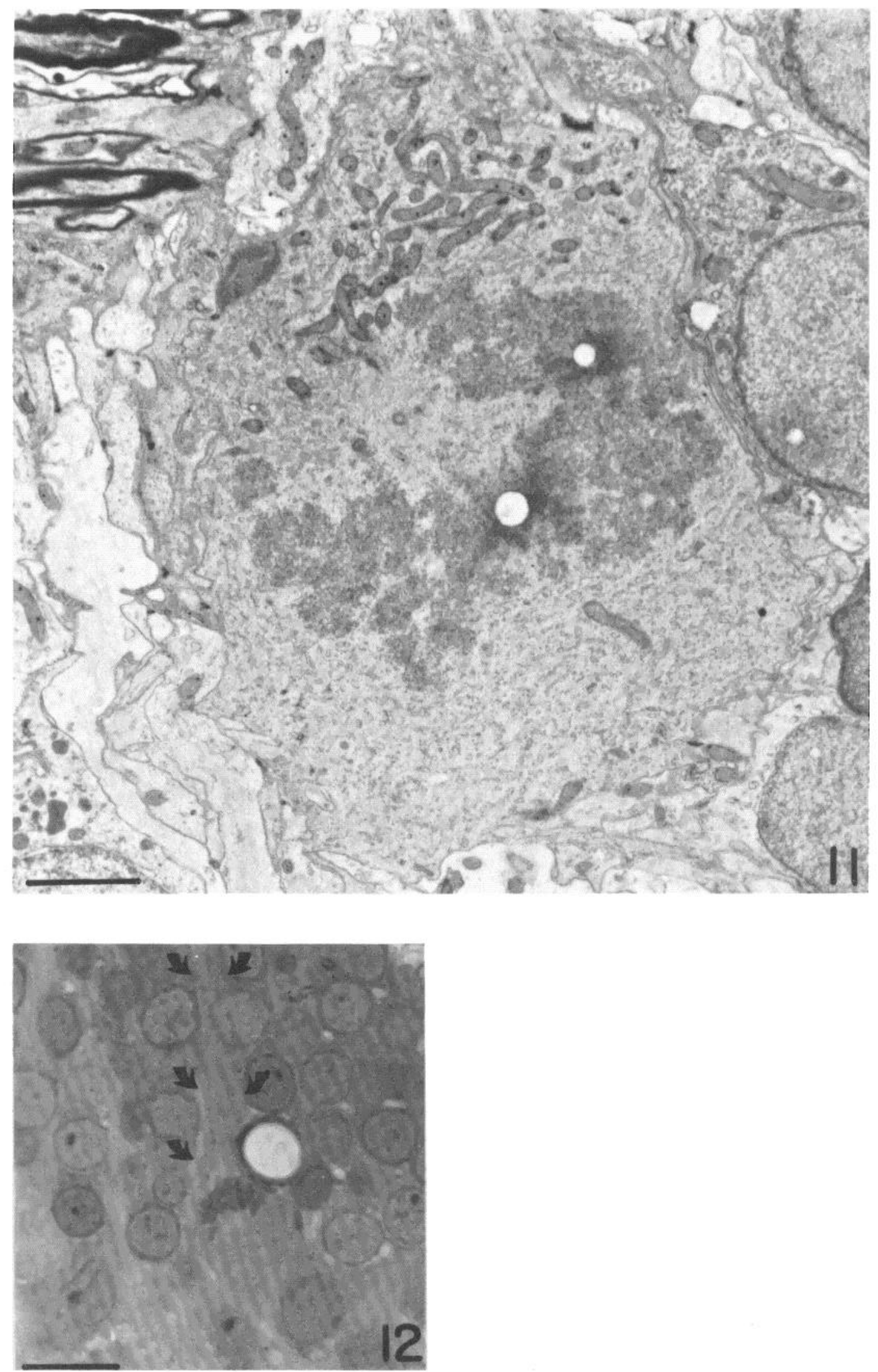

Figure 11 (upper). Electron micrograph of a mitotic radial glia. The condensed chromosomes occupy the central region of the cell's soma. Granule-bearing mitochondria are clustered near the apical pole of the soma. Scale bar $=2 \mu \mathrm{m}$.

Figure 12 (lower). A mitotic radial glial cell in early anaphase. The radial process (arrows) of this dividing cell is prominent as it extends outward through SPV. Scale bar $=10 \mu \mathrm{m}$. 


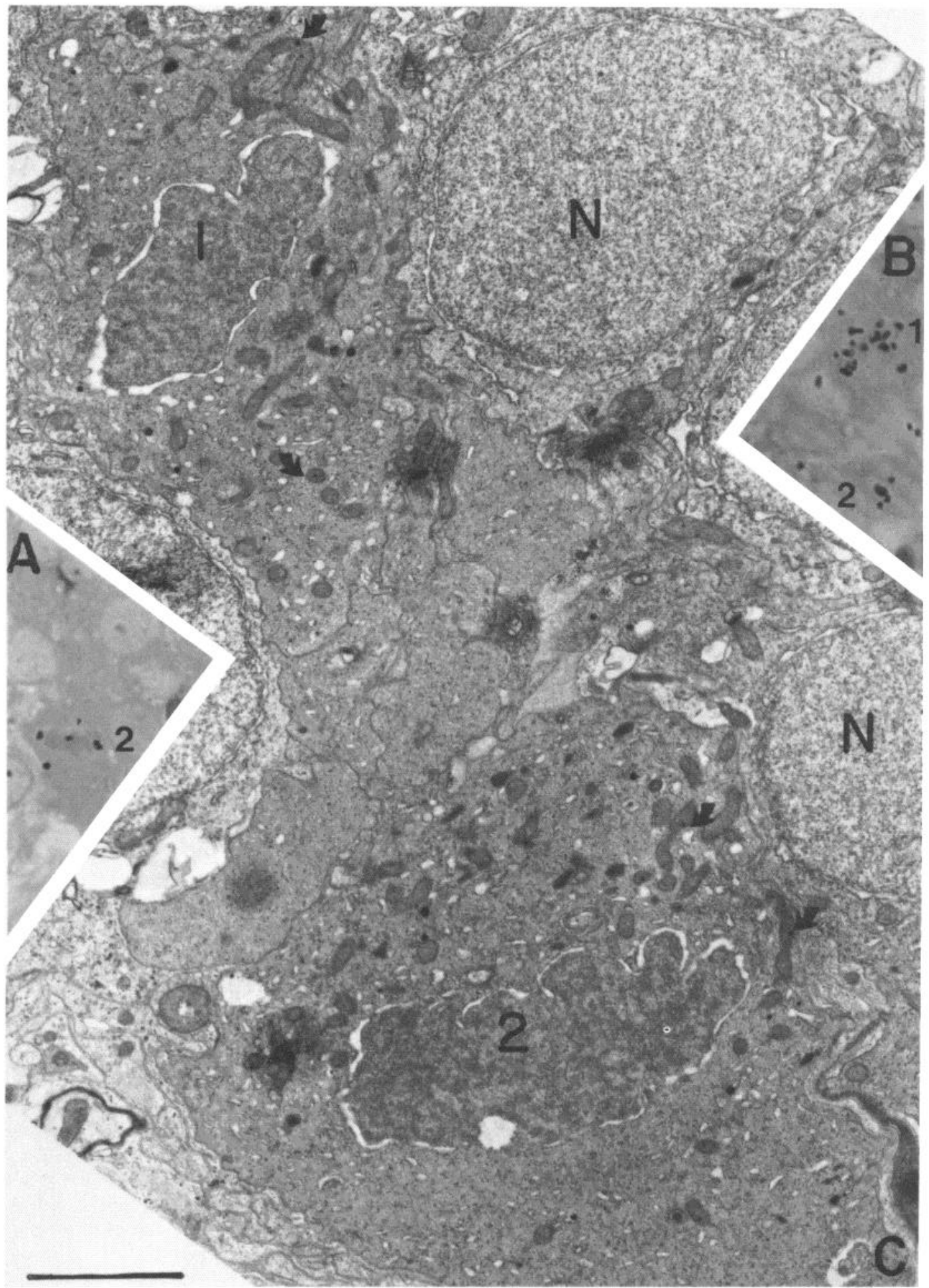

Figure 13. Daughter products of a mitotic division of a radial glia. $A$ and $B$, Light microscopic autoradiograms showing a pair of radially adjacent daughter cells. Cell 1, Outer daughter; cell 2, inner daughter. This tissue was obtained from a fish $24 \mathrm{hr}$ after $\left[{ }^{3} \mathrm{H}\right] \mathrm{TdR}$ injection. $C$, Electron micrograph of an adjacent thin section. It shows the two daughter cells, 1 and 2 . Both cells contain mitochondria with dark granules (arrows). $N$, nucleus of a periventricular neuron. Scale bar $=2$ $\mu \mathrm{m}$.

Yoon, 1978, 1980), are not neurons but radial glial cells of the subventricular zone of the adult goldfish tectum. Furthermore, these radial glia which undergo mitotic cell division are not simply undifferentiated germinal cells. In fact, they are morphologically distinct cells with promi- nent radial processes which extend through the entire depth of the tectal layers. These radial glia incorporate exogenous $\left[{ }^{3} \mathrm{H}\right]$ thymidine into new DNA as early as $2 \mathrm{hr}$ after systemic injection. Some labeled radial glial cells can be identified at different mitotic stages between 12 


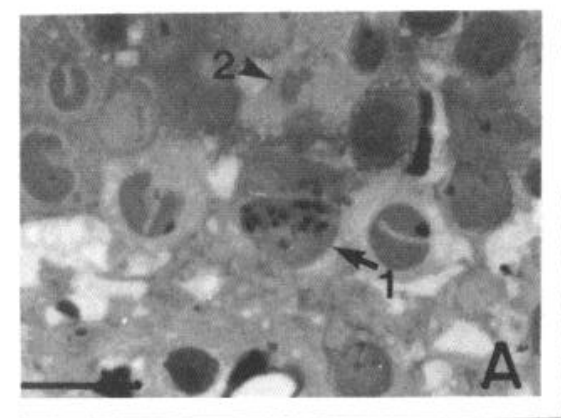

14
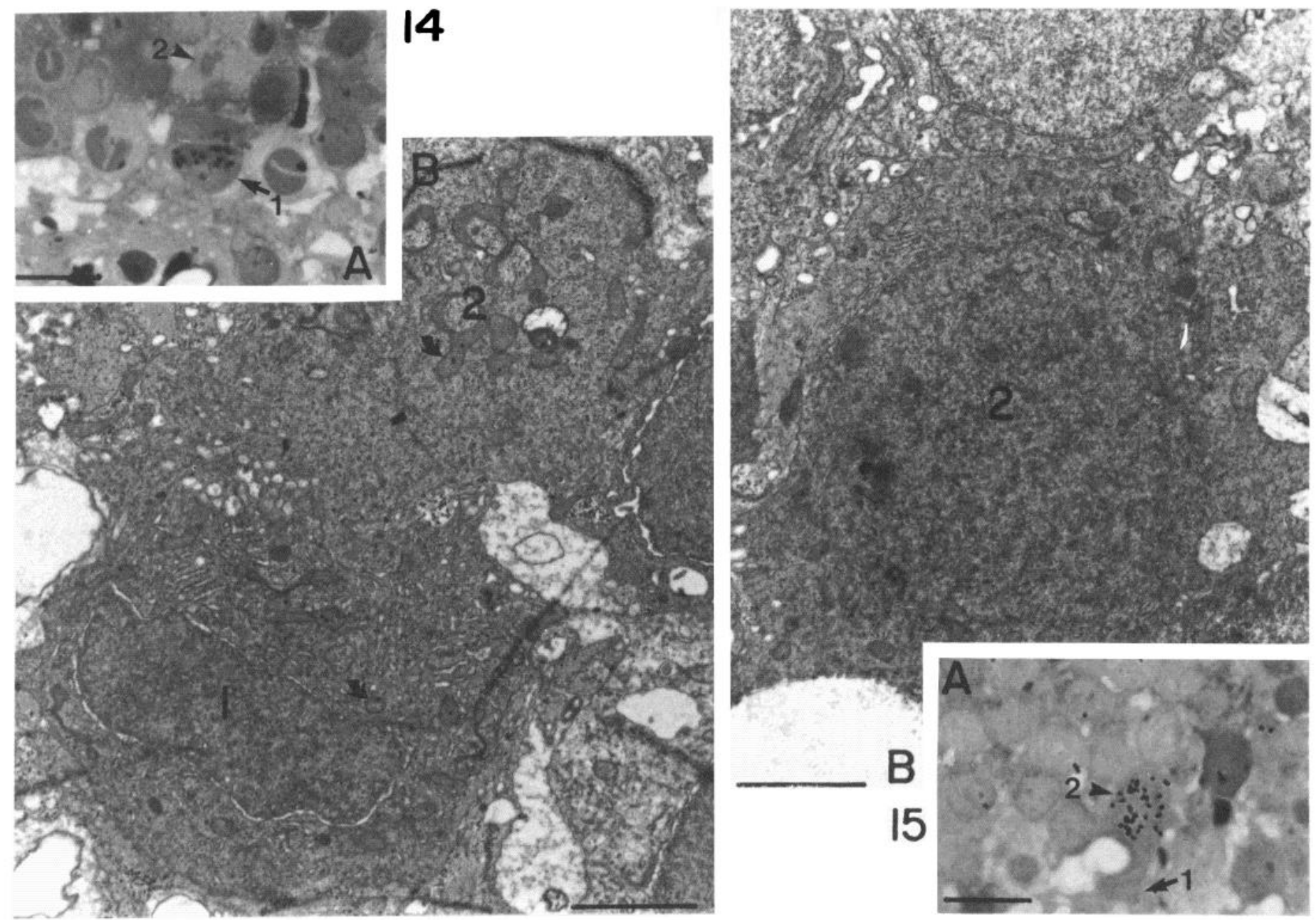

Figures 14 (left) and 15 (right). Radially adjacent pair of labeled radial glial cells. A, Light microscopic autoradiograms of the inner cell (1) and the outer cell (2) labeled $12 \mathrm{hr}$ after $\left[{ }^{3} \mathrm{H}\right] \mathrm{TdR}$ injection. Scale bar: $10 \mu \mathrm{m}$ for Figures $14 A$ and $15 A$. B, Electron micrographs of adjacent thin sections. Both cells contain mitochondria with dark granules (arrows). Scale bar $=2 \mu \mathrm{m}$ for Figures $14 B$ and $15 B$.

and $24 \mathrm{hr}$ after $\left[{ }^{3} \mathrm{H}\right] \mathrm{TdR}$ injection. In a few cases, radially aligned pairs of labeled daughter radial glial cells are observed as early as $12 \mathrm{hr}$ and also as late as 51 days after $\left[{ }^{3} \mathrm{H}\right] \mathrm{TdR}$ injection.

These observations suggest that radial glia might undergo a semi-conservative type of cell division, with one daughter retaining the specialized radial process of the parent cell. The plane of mitotic division for these cells is always aligned to the equator of the cell body, perpendicular to the radial direction of the process. This type of mitosis could allow the newly born daughter cell, located above the equator, to retain the outward radial process and the other daughter cell (below the equator) to retain the inward process (if present) of their common precursor. In some cases, it is possible to observe that both of the $\left[{ }^{3} \mathrm{H}\right] \mathrm{TdR}$-labeled daughter cells are radial glial cells, which are paired along the radial axis of the tectal layers. In a number of other cases, however, only one daughter radial glial cell shows $\left[{ }^{3} \mathrm{H}\right] \mathrm{TdR}$ labeling in its nucleus, and the other daughter cell cannot be traced. The latter may have migrated radially from the periependymal zone or laterally within it. Alternatively, the unidentified daughter cell may have undergone further divisions (and thus diluted its $\left[{ }^{3} \mathrm{H}\right] \mathrm{TdR}$ label), differentiated along different cell lines, or died.

The mitotic activities of the periependymal radial glial cells, observed in the adult goldfish tectum during its reinnervation by retinal fibers, are somewhat similar to those of other subependymal cells, observed in the embryonic or neonatal mammalian brains (Smart, 1961). Some of the subependymal cells give rise to astrocytes and oligodendrocytes (Privat and Leblond, 1972; Paterson et al., 1973), whereas others become ependymal cells, and many of them eventually die (Blakemore and Jolly, 1972). The ultrastructures of these mitotically active subependymal cells showed considerable variations within and between species. Privat and Leblond (1972) described subependymal cells with invaginated nuclei containing clumped chromatin in the rat. The cytoplasm of these cells was dense and it contained free ribosomes, mitochondria with dense granules, and prominent microtubular systems. These features are very similar to the periependymal radial glial cells of the adult goldfish tectum (J. A. Stevenson and M. G. Yoon, submitted for publication). In the dog brain, Blakemore and Jolly (1972) observed that subependymal cells had pale nuclei 

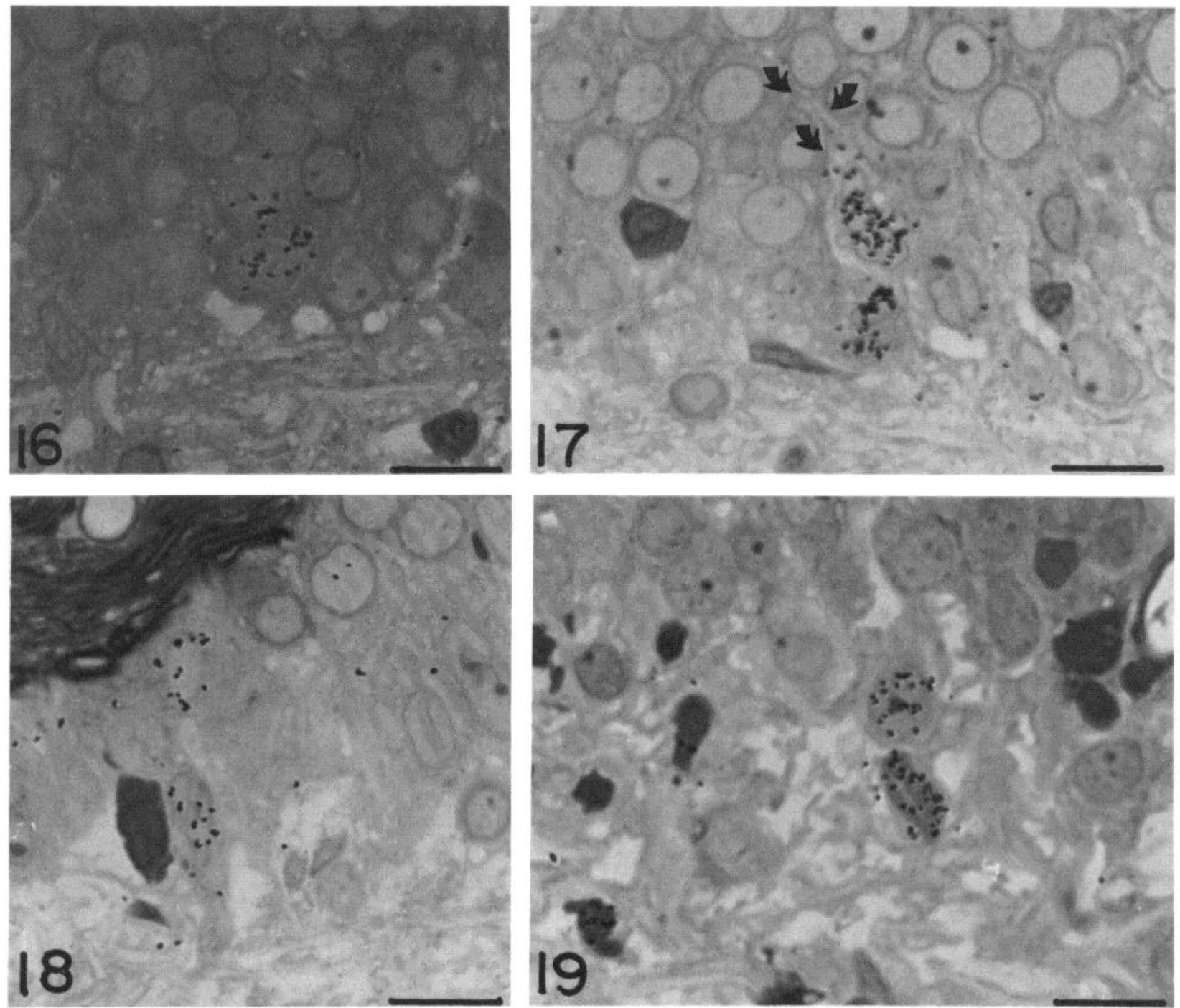

Figure 16 (upper left). A radially adjacent pair of radial glial cells labeled $24 \mathrm{hr}$ after $\left[{ }^{3} \mathrm{H}\right] \mathrm{TdR}$ injection. Scale bar $=10 \mu \mathrm{m}$.

Figure 17 (upper right). A radially adjacent pair of cells labeled $48 \mathrm{hr}$ after $\left[{ }^{3} \mathrm{H}\right] \mathrm{TdR}$ injection. A radial process of the outer cell is indicated by arrows. Scale bar $=10 \mu \mathrm{m}$.

Figure 18 (lower left). Two radial glial cells labeled $48 \mathrm{hr}$ with $\left[{ }^{3} \mathrm{H}\right] \mathrm{TdR}$ injection. The pair is oriented radially. Scale bar $=10$ $\mu \mathrm{m}$.

Figure 19 (lower right). A pair of radial glial cells which retain the label 51 days after $\left[{ }^{3} \mathrm{H}\right] \mathrm{TdR}$ injection. They also remain radially adjacent to each other. Scale bar $=10 \mu \mathrm{m}$.

and clear cytoplasm which contained microfilaments and well developed Golgi apparatus. Stensaas and Gilson (1972) observed in the rabbit brain that the subependymal cells had dark cytoplasm which contained microtubules and free ribosomes. Rakic (1972) found in the embryonic monkey cerebral cortex that the subventricular radial glia contained many microtubules in their cytoplasm but lacked microfilaments at early stages. These glial cells, which provide radial guidance to migrating neuroblasts, remain amitotic for a considerable period during embryonic development, but they resume mitotic activities at a later period after the migration of neuroblasts is completed (Schmechel and Rakic, 1979a). These radial glial cells eventually transform into astrocytes in developing monkey telencephalon (Schemechel and Rakic, 1979b).

Cell proliferations after optic nerve section were ob- served in the newt optic tectum (Gaze and Watson, 1968) and in the frog optic tectum (Gruberg and Stirling, 1974). These proliferations also may have been dependent on reinnervation of the tectum by regenerating optic fibers. Based on observations of iron hematoxylin preparations, Gaze and Watson (1968) claimed that the cells which were labeled in the newt tectum were "ependymal glial cells," but no further cytological investigations of their cell type was carried out.

In view of the above comparison, the radial glial cell of the adult goldfish tectum may be regarded as an embryonic-like subventricular cell which retains a capacity for mitosis even at adulthood. Regenerating axons of the retinal ganglion cells seem to exert a mitogenic influence upon the radial glial cells. Consequently, mitotic activities are resumed in at least some of these radial glia. The nature of the mitogenic interactions between the ingrow- 

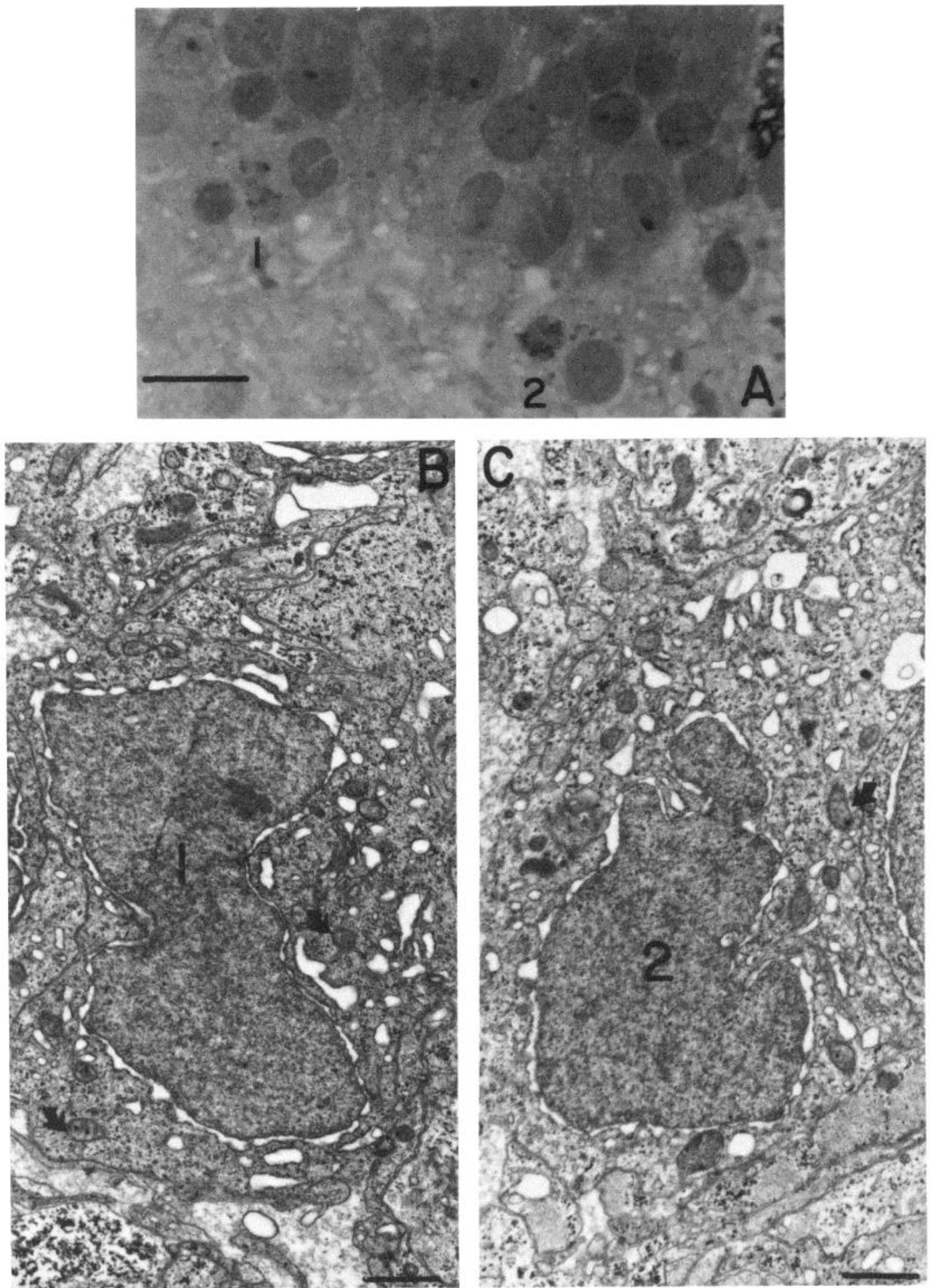

Figure 20. Two separate radial glial cells labeled $48 \mathrm{hr}$ after $\left[{ }^{3} \mathrm{H}\right] \mathrm{TdR}$ injection. $A$, Light microscopic autoradiogram of two labeled cells, 1 and 2 , within the periependymal region. Scale bar $=10 \mu \mathrm{m} . B$, Electron micrograph of cell 1. C, Electron micrograph of cell 2 . Both cells 1 and 2 have mitochondria with dark granules (arrows), microtubules, and invaginated nuclei. Scale bar $=1 \mu \mathrm{m}$.

ing axons of the retinal ganglion cells and the radial glial cells remains to be elucidated.

\section{References}

Blakemore, W. F., and R. D. Jolly (1972) The subependymal plate and associated ependyma in the dog. An ultrastructural study. J. Neurocytol. 1: 69-84.
Gaze, R. M., and W. E. Watson (1968) Cell division and migration in the brain after optic nerve lesions. In Growth of the Nervous System, G. Wolstenholme and M. O'Connor, eds., pp. 53-67, Little Brown, Boston.

Gruberg, E. R., and R. V. Stirling (1974) An autoradiographic study of changes in the frog tectum after cutting the optic nerve. Brain Res. 76: 359-362.

Johns, P. R., S. S. Easter, J. A. Burnham, and M. K. Powers 
(1977) Regenurating optic fibers stimulate tectal cell proliferation in the goldfish. Anat. Kec. 187: 615-616.

Panayi, G. S., and W. A. Neill (1972) Scintillation autoradiography-a rapid technique. J. Immunol. Methods 2: 115-117.

Paterson, J. A., A. Privat, E. F. Long, and C. P. Leblond (1973) Investigation of glial cells in semi-thin sections. III. Transformation of subependymal cells into glial cells, as shown by radioautography after ${ }^{3} \mathrm{H}$-thymidine injection into the lateral ventricle of the brain of young rats. J. Comp. Neurol. 149: 83-102.

Privat, A., and C. P. Leblond (1972) The subependymal layer and neighboring region in the brain of the young rat. $J$. Comp. Neurol. 146: 227-302.

Rakic, P. (1972) Mode of cell migration to the superficial layers of the fetal monkey neocortex. J. Comp. Neurol. 145: 61-84.

Schmechel, D. E., and P. Rakic (1979a) Arrested proliferation of radial glial cells during midgestation in rhesus monkey. Nature 277: 303-305.

Schmechel, D. E., and P. Rakic (1979b) A Golgi study of radial glial cells in developing monkey telencephalon: Morphogenesis and transformation into astrocytes. Anat. Embryol. (Berl.) 156: 115-152.

Sidman, R. L. (1970) Autoradiographic methods and principles for study of the nervous system with thymidine- $\mathrm{H}^{3}$. In Contemporary Research Methods in Neuroanatomy, W. Nauta and S. Ebbesson, eds., pp. 252-274, Springer-Verlag, Berlin.

Smart, I. (1961) The subependymal layer of the mouse brain and its cell proliferation as shown by radioautography after thymidine- $\mathrm{H}^{3}$ injection. J. Comp. Neurol. 116: 325-347.

Smith, D. M., S. A. Shelley, and J. U. Balis (1979) Reduced cell proliferation in fetal lung after maternal administration of pilocarpine. A scintillation autoradiographic study. Am. J. Anat. 155: 131-137.

Stensaas, L. J., and B. C. Gilson (1972) Ependymal and subependymal cells of the caudotopallial junction in the lateral ventricle of the neonatal rabbit. Z. Zellforsch. Mikrosk. Anat. 132: 297-322.

Stevenson, J. A. (1976) Post-operative cell proliferation in the goldfish optic tectum. Soc. Neurosci. Abstr. 2: 837.

Stevenson, J. A. (1977) Cell proliferation in the "compressing" optic tectum of goldfish. Soc. Neurosci. Abstr. 3: 432.

Stevenson, J. A. (1979) Reinnervation induces proliferation of a novel form of radial glia in the optic tectum of goldfish. Soc. Neurosci. Abstr. 5: 636 .

Stevenson, J. A., and M. G. Yoon (1978) Regeneration of optic nerve fibers enhances cell proliferation in the goldfish optic tectum. Brain Res. 153: 345-351.

Stevenson, J. A., and M. G. Yoon (1980) Kinetics of cell proliferation in the halved tectum of adult goldfish. Brain Res. 184: 11-22.

Yoon, M. G. (1976) Progress of topographic regulation of the visual projection in the halved optic tectum of adult goldfish. J. Physiol. (Lond.) 257: 621-643. 